\title{
Emulsifying Properties of a Mixture of Peptides Derived from the Enzymatic Hydrolyzates of Bovine Caseins
}

\author{
Soo Won Lee, Makoto Shimizu, Shuichi Kaminogawa, \\ and Kunio Yamauchi \\ Department of Agricultural Chemistry, The University of Tokyo, \\ Bunkyo-ku, Tokyo 113, Japan
}

Received November 11, 1986

\begin{abstract}
$\beta$-CN(f193-209), a hydrophobic peptide of 17 residues obtained from the chymosin hydrolyzate of $\beta$-casein, had little emulsifying activity (EA) at a neutral $\mathrm{pH}$. When mixed with a hydrophilic glycomacropeptide (GMP) derived from $\kappa$-casein however, the EA of $\beta$-CN(f193-209) increased greatly. The mixing ratio of the peptides affected the EA as well as the adsorption of the peptides to oil droplets. Scanning electron microscopy indicated that the peptide film surrounding the emulsified oil droplets was thick and rough compared to the protein film. An amphipathic structure formed by some interaction between the hydrophilic GMP and the hydrophobic $\beta$ $\mathrm{CN}$ (f193-209) might contribute to the formation of the thick peptide film and stabilize the emulsified oil.
\end{abstract}

Recent developments in reversed phase-high performance liquid chromatography have made it possible to separate or analyze peptides of medium chain length $(15 \sim 30$ residues). These peptides are commonly produced by limited hydrolysis of various proteins and probably have different functional properties from those of proteins. Since the limited hydrolysis of proteins is considered to be useful in changing the functional properties of food proteins, ${ }^{1 \sim 5)}$ it is important to know the characteristic of such medium-chain peptides formed by limited proteolysis. However, the information available is very limited.

In our preceding papers, ${ }^{6,7)}$ we reported the emulsifying properties of three peptides of $2000 \sim 3000$ daltons, which were prepared from the enzymatic hydrolyzates of $\alpha_{\mathrm{s} 1}$ - and $\beta$ casein. These peptides had poor emulsifying properties at neutral pHs. During these studies, however, we found that some "crude" peptide fractions had very high emulsifying activity. For example, the $\mathrm{pH} 4$.6-soluble fraction of the chymosin hydrolyzate of $\beta$-casein, which contained the $\mathrm{C}$-terminal 17 residues as a major peptide and was termed the crude $\beta$ -
$\mathrm{CN}(\mathrm{f} 193-209)$ fraction, had high emulsifying activity, but the emulsifying activity of the pure $\beta$-CN(f193-209) peptide was very low. Existence of some peptide(s) having good emulsifying properties in this fraction was, therefore, suggested.

In this study, we tried to isolate and identify the peptides in this crude $\beta$ - $\mathrm{CN}(\mathrm{f} 193-209)$ fraction. The cooperative or synergistic effect between $\beta$-CN(f193-209) and other peptides on emulsification was observed. Localization of these peptides at emulsified oil globule surfaces was investigated biochemically. The mechanism of emulsification by these peptides was also discussed in comparison with that by the proteins.

\section{MATERIALS AND METHODS}

Preparation of $\beta$ - and $\kappa$-caseins. The crude $\beta$-casein was prepared by the method of Fox and Guiney, ${ }^{8)}$ and purified as described previously. ${ }^{7)} \kappa$-casein was isolated from isoelectric whole casein by the urea-sulfuric acid method ${ }^{9}$ followed by precipitation with ethanol.

Isolation of the crude $\beta$-CN(f193-209) fraction. A $2 \%$ solution of $\beta$-casein in $0.01 \mathrm{~m}$ imidazole- $\mathrm{HCl}$ buffer $(\mathrm{pH}$ 
6.5) was incubated with chymosin (Difco) at $10^{\circ} \mathrm{C}$ for $3 \mathrm{hr}$ $(\mathrm{E} / \mathrm{S}$ ratio $=1: 5, \mathrm{w} / \mathrm{w})$. After incubation, the solution was heated for $5 \mathrm{~min}$ at $80^{\circ} \mathrm{C}$ to inactivate the enzyme. The solution was acidified to $\mathrm{pH} 4.6$, and centrifuged at $1840 \times g$ for $10 \mathrm{~min}$. The supernatant was repeatedly diluted and concentrated on a G-01T membrane filter (ULVAC Service Co.) at $4^{\circ} \mathrm{C}$ until free from salts.

Fractionation of the crude $\beta-C N(f 193-209)$ fraction. A $2 \%$ solution of the crude $\beta$-CN(f 193-209) fraction was fractionated using a Bio-Gel P-30 column (Bio-Rad Laboratories; $2 \times 38 \mathrm{~cm}$ ) which had been equilibrated with $10 \mathrm{~mm}$ imidazole- $\mathrm{HCl}$ buffer ( $\mathrm{pH} 6.5$ ).

Isolation of the glycomacropeptide (GMP) from $\kappa$-casein. A $1.5 \%$ solution of $\kappa$-casein in $50 \mathrm{~mm}$ imidazole- $\mathrm{HCl}$ buffer ( $\mathrm{pH}$ 6.5) was incubated with chymosin at $35^{\circ} \mathrm{C}$ for $10 \mathrm{~min}(\mathrm{E} / \mathrm{S}$ ratio $=1: 100, \mathrm{w} / \mathrm{w})$. After incubation, the solution was heated at $80^{\circ} \mathrm{C}$ for $5 \mathrm{~min}$ to inactivate the enzyme. The solution was acidified to $\mathrm{pH} 4.6$ and centrifuged at $1840 \times g$ for $10 \mathrm{~min}$. The supernatant was chromatographed on a CM-Sephadex C-25 column in $50 \mathrm{~mm}$ imidazole- $\mathrm{HCl}$ buffer ( $\mathrm{pH}$ 6.5). The first fraction passed through the column was collected and dialyzed against water.

High performance liquid chromatography (HPLC). A high performance liquid chromatograph (Tri-Rotor SR-2, Jasco) was fitted with a LiChrosorb RP-18 column $(4.0 \times 250 \mathrm{~mm})$ and a UV detector at a wavelength of $230 \mathrm{~nm}$. Elution was done with $0.1 \%$ trifluoroacetic acid (TFA)-acetonitrile as a mobile phase at a flow rate of $1 \mathrm{ml} / \mathrm{min}$. The concentration of the mobile phase modifier (acetonitrile) was increased linearly from $0 \sim 95 \%$ over $60 \mathrm{~min}(1.58 \% / \mathrm{min})$.

Amino acid analysis. A peptide fraction separated on HPLC was evaporated to remove TFA and acetonitrile, and was dissolved in $6 \mathrm{~N} \mathrm{HCl}$. The solution was degassed and hydrolyzed at $110^{\circ} \mathrm{C}$ for $24 \mathrm{hr}$. The hydrolyzate was analyzed with an automatic amino acid analyzer (Model 835, Hitachi).

Preparation of the emulsion. Emulsion was prepared by homogenizing a $2 \%$ peptide solution in $5 \mathrm{~mm}$ phosphate buffer (pH 7.0) and 20\% soybean oil (Sanko Pharmaceutical Co.) at $30^{\circ} \mathrm{C}$ with a Polytron PTA-7 (Kinematica) for $3 \mathrm{~min}$ at full speed $(19,500 \mathrm{rpm})$. Emulsifying activity was measured by the procedure of Pearce and Kinsella ${ }^{10)}$ and presented in terms of the emulsifying activity index (EAI).

Isolation of peptides adsorbed on the oil globule surface during emulsification. The emulsion was mixed with 2 volumes of $5 \mathrm{~mm}$ phosphate buffer $(\mathrm{pH} 7.0)$ and centrifuged at $1840 \times g$ for $15 \mathrm{~min}$ at room temperature. The aqueous phase was removed by aspiration. The peptide adsorbed on the oil globule surface was recovered by delipidating the cream phase with a methanol-chloroform mixture $(1: 2, \mathrm{v} / \mathrm{v})$.

Agglutination test of oil globules with lectins. Soybean agglutinin (SBA; from Glycine max) and peanut agglutinin (PNA; from Arachis hypogaea) were obtained from E. Y. Laboratories. Washed cream was suspended in $50 \mathrm{~mm}$ phosphate buffer ( $\mathrm{pH}$ 7.3) so as to give an oil content of about $5 \%(\mathrm{w} / \mathrm{v})$. Lectins were dissolved in the same buffer to the concentration of $2 \mathrm{mg} / \mathrm{ml}$. A suspension of the washed oil globules $(25 \mu \mathrm{l})$ was mixed with a lectin solution $(25 \mu \mathrm{l})$ on a microtiter plate. The agglutination was allowed to proceed at room temperature for $1 \mathrm{hr}$ with gentle stirring.

Staining of washed oil globules with fluorescein-labelled agglutinin. Fluorescein isothiocyanate-labelled soybean agglutinin (FITC-SBA) was purchased from E. Y. Laboratories. The washed oil globule suspension $(100 \mu \mathrm{l})$ was incubated with a FITC-SBA solution $(200 \mu \mathrm{l})$ for $30 \mathrm{~min}$ at $37^{\circ} \mathrm{C}$. The oil globules were then centrifuged at $1840 \times g$ for $10 \mathrm{~min}$ and the floating cream was washed with the phosphate buffer. The washed oil globules were examined in a Olympus BH-2-RFK fluorescence microscope with UV illumination.

Electron microscopic observation. We used a Hitachi S800 scanning electron microscope with a cryosystem as described previously. ${ }^{6}$ )

\section{RESULTS}

\section{Characterization of the crude $\beta-C N(f 193-209)$ peptide fraction}

The crude $\beta$-CN(f193-209) fraction from the cymosin hydrolyzate of $\beta$-casein had a much higher EAI value than the pure $\beta$ - $\mathrm{CN}$ (f193209) peptide (Table I). By HPLC analysis on an ODS column, the crude fraction had one major peak corresponding to $\beta$-CN(f193-209), together with some small peaks (Fig. 1, arrowhead). By gel filtration on a Bio-Gel P-30

Table I. Emulsifying Activity of the Bio-Gel P-30 Fractions AND Their MiXTure

\begin{tabular}{lr}
\hline & EAI $\left(\mathrm{m}^{2} / \mathrm{g}\right)$ \\
\hline Crude $\beta$-CN (f193-209) fraction & $38.1 \pm 0.2$ \\
Fraction I $^{a}$ & $13.6 \pm 0.6$ \\
Fraction II $^{b}$ & $8.2 \pm 0.8$ \\
Fraction I + Fraction II & $31.1 \pm 0.9$ \\
\hline
\end{tabular}

a GMP

b $\quad \beta$-CN (f193-209). 


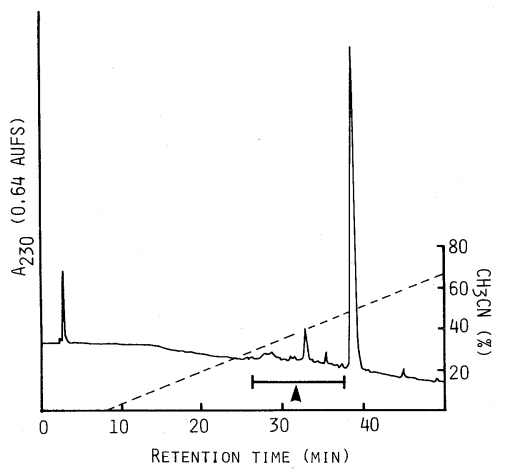

FIG. 1. HPLC Pattern of the Crude $\beta$-CN(f193-209) Fraction.

Column, LiChrosorb RP-18 $(4.0 \times 250 \mathrm{~mm}$ i.d. $)$; primary solvent, $0.1 \%$ trifluoroacetic acid; secondary solvent, $95 \%$ acetonitrile. The gradient profile is shown by the dotted line.

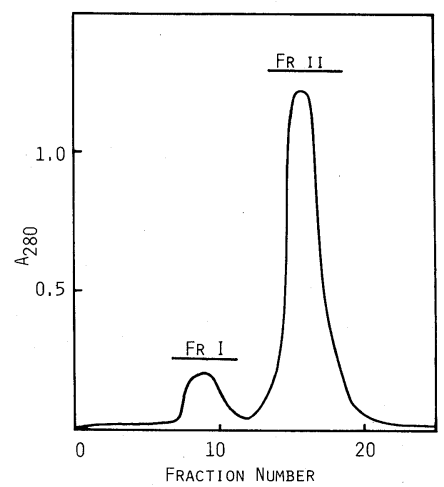

FIG. 2. Gel Filtration of the Crude $\beta$-CN(f193-209) Fraction on Bio-Gel P-30 (Gel Bed, $20 \times 380 \mathrm{~mm}$ ).

column, the crude fraction was divided into 2 fractions (Fig. 2). The HPLC pattern of Fraction I (Fig. 3A) was the same as that of the minor peaks observed in Fig. 1. On the other hand, Fraction II had only one peak which corresponded to the $\beta$-CN(f193-209) peptide. The eluates corresponding to the peaks No. $1 \sim 5$ of Fraction I (Fig. 3A) contained carbohydrate and their amino acid composition was very similar to that of the glycomacropeptide (GMP), $\kappa$-CN(f106-169), indicating the identity of Fraction I as GMP (data not shown). GMP is considered to be derived from the small amounts of $\kappa$-casein in the $\beta$-casein fraction, from which $\beta$ - $\mathrm{CN}$ (f 193209) was isolated. Doi et al. ${ }^{11)}$ reported that

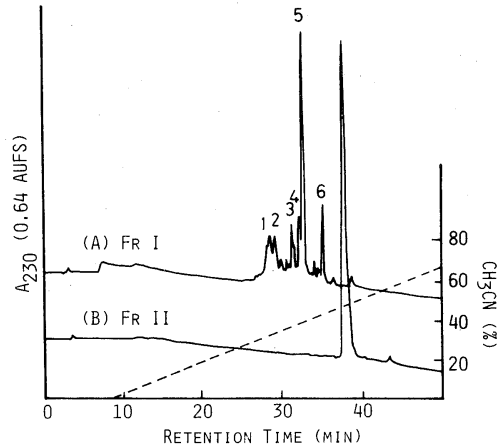

FIG. 3. HPLC Patterns of the Bio-Gel P-30 Fractions. Fractions I and II are defined in Fig. 2. Conditions for HPLC are same as in Fig. 1.

bovine $\kappa$-casein consisted of five major and two minor components all containing one phosphate group. The heterogeneous pattern of GMP on HPLC (Fig. 3A) seems to reflect such heterogeneity of $\kappa$-casein.

Interaction of $\beta-C N(f 193-209)$ and GMP in an aqueous solution

A mixture of $\beta$-CN(f193-209) and GMP in $5 \mathrm{~mm}$ phosphate buffer $(\mathrm{pH} 7.0)$ was put on a Sephadex G-75 column. The peptides were separately eluted (data not shown), indicating that no complex formation between $\beta$ $\mathrm{CN}(\mathrm{f} 193-209)$ and GMP occurred in aqueous solution. No substantial decrease in the surface tension upon mixing the peptides was observed (data not shown).

\section{Emulsification with the peptide mixture}

As shown in Table I, the emulsifying activity values of the pure $\beta$-CN(f193-209) peptide (Fraction II) and GMP (Fraction I) were very low, although the crude $\beta$-CN(f193-209) fraction had high emulsifying activity. The $\beta$ CN(f193-209) peptide was, therefore, mixed with GMP at the primary ratio and the emulsifying activity of the mixture was measured. An increase in the EAI value by mixing the two peptides was confirmed.

The effects of the mixing ratio of the two peptides on the emulsifying activity were investigated using $2 \%$ peptide solutions in $5 \mathrm{~mm}$ 


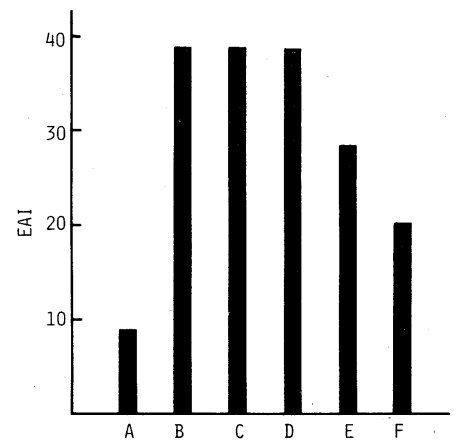

FIG. 4. Effects of the Mixing Ratio on the Emulsifying Activity Index (EAI) of the Mixture of $\beta$-CN(f193-209) and GMP.

The total peptide concentration is $2 \% . \quad \beta-\mathrm{CN}(\mathrm{f} 193-$ 209)/GMP ratios are $7 / 1(\mathrm{~B}), 3 / 1(\mathrm{C}), 1 / 1(\mathrm{D})$ and $1 / 3(\mathrm{E})$. EAI values of $\beta-\mathrm{CN}(\mathrm{f} 193-209)$ and GMP are shown in (A) and $(\mathrm{F})$, respectively.

phosphate buffer ( $\mathrm{pH}$ 7.0). Figure 4 indicated that the mixture of a small amount of GMP with $\beta$-CN(f 193-209) increased the EAI.

The ratio of $\beta-\mathrm{CN}(\mathrm{f} 193-209)$ and GMP adsorbed on the emulsified oil surface was investigated. The peptides adsorbed on the oil globule surface were isolated from the washed oil globules and the ratio of the two peptides was examined by HPLC analysis. The ratio of the two peptides on the oil globule surface was similar to that in the peptide solution used for emulsification (Table II).

Localization of GMP in the surface layer covering the emulsified oil

GMP has a carbohydrate moiety in its molecule, which might play some role in stabilization of the emulsified oil droplets. An emulsion was prepared with a mixture of $\beta$ $\mathrm{CN}(\mathrm{f} 193-209)$ and GMP, and localization of GMP in the adsorbed layer was investigated using lectins. Soybean and peanut agglutinins agglutinated the oil droplets (Table III), suggesting that GMP, particulary its carbohydrate moiety, is on the outer surface of the oil droplets. Figure 5 shows a fluorescence microgram of the emulsion treated with FITClabelled soybean lectin. The outer surface of the oil droplets has fluorescence, indicating
Table II. EFFects of the Mixing Ratio of $\beta$-CN (f193-209) AND GMP ON THEIR Adsorption to the Oil Globule

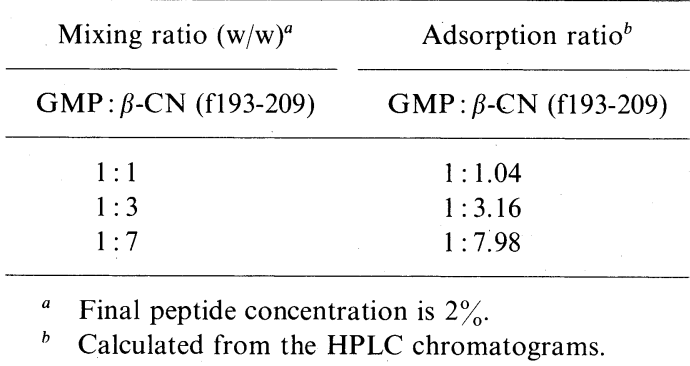

Table III. Agglutination by Lectins of the Washed Oil Globules in the Emulsion Prepared WITH $\beta$-CN (f193-209) AND GMP

\begin{tabular}{lc}
\hline \multicolumn{1}{c}{ Lectins } & Agglutination \\
\hline Peanut agglutinin (PNA) & + \\
Soybean agglutinin (SBA) & + \\
${\text { SBA }+ \text { galactose }^{a}}$ & - \\
\hline
\end{tabular}

a Negative control (D-galactose is a receptor sugar for SBA and specifically inhibits the binding of glycoproteins to SBA).

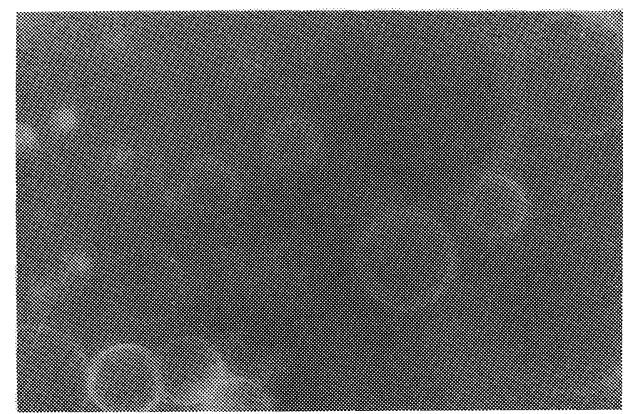

Fig. 5. Fluorescent Images of the Oil Globules Stabilized in a Mixture of $\beta-\mathrm{CN}(\mathrm{f} 193-209)$ and GMP $(1: 1$, w/w) after Exposure to FITC-Soybean Lectin.

that the carbohydrate moiety of GMP is on the outer surface and accessible to the lectin.

\section{Microscopic observation}

Phase contrast microscopic observation of the emulsion prepared with $\beta-\mathrm{CN}(\mathrm{f} 193-209)$ and GMP (mixing ratio, 1:1, w/w) at $\mathrm{pH} 7$ showed finer dispersion of oil droplets, compared with those prepared by either $\beta$ $\mathrm{CN}(\mathrm{f} 193-209)$ or GMP alone. Figure 6 shows the scanning electron micrographs of the 

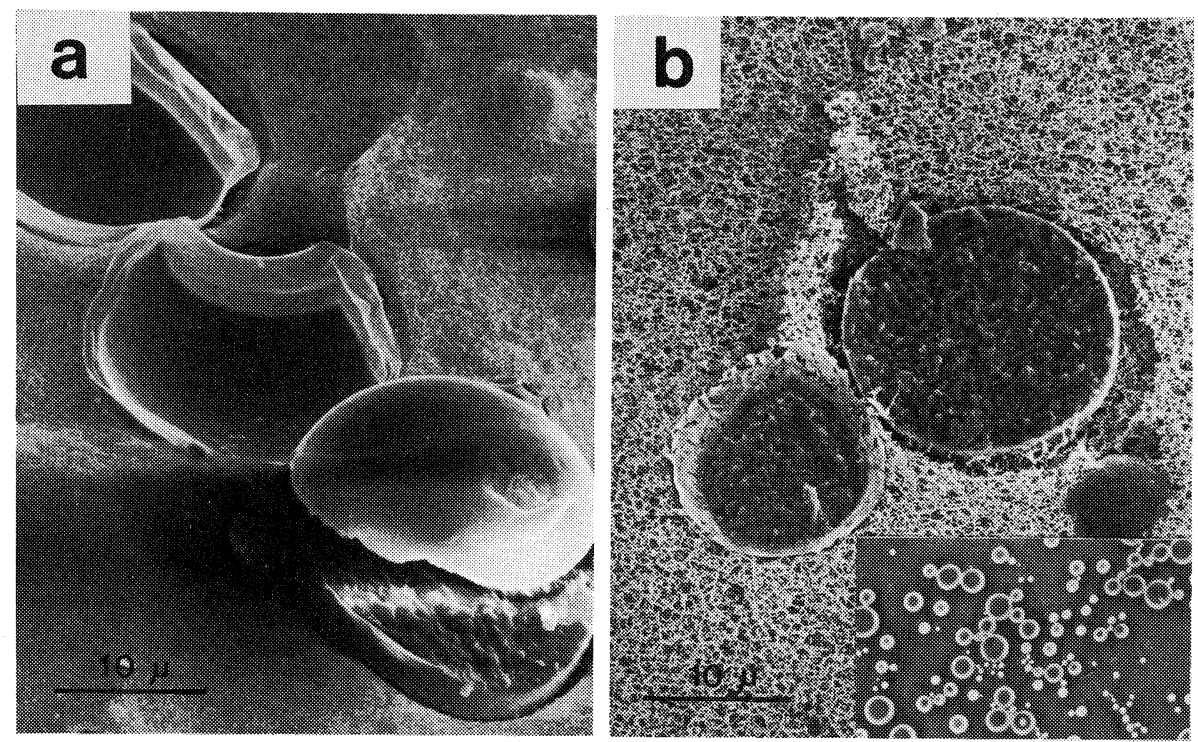

Fig. 6. Scanning Electron Micrographs of the Emulsions Prepared with $\beta$-Casein (a) and a Mixture of $\beta$-CN(f193-209) and GMP (b).

Insert is a phase contrast microscopic observation of the emulsion (b).

emulsions prepared with $\beta$-casein (a) and with the mixture of $\beta$-CN(f193-209) and GMP (b). $\beta$-Casein formed a very smooth, thin film surrounding the oil droplets, while the peptide mixture formed a thick, rough film.

\section{DISCUSSION}

In our preceding paper, ${ }^{7)}$ we reported that the pure $\beta-\mathrm{CN}(\mathrm{f} 193-209)$ peptide had a low emulsifying activity. However, this study revealed that the crude $\beta-\mathrm{CN}(\mathrm{f} 193-209)$ fraction, which contained a small amount of GMP, had a high emulsifying activity. Each of the two peptides, $\beta$-CN(f 193-209) and GMP, obtained from the crude $\beta$ - $\mathrm{CN}(\mathrm{f} 193-209)$ fraction had a low emulsifying activity, while the mixture of the two at the primary ratio had a very high EAI value. This result suggests that some kind of interaction between $\beta-\mathrm{CN}(\mathrm{f} 193-209)$ and GMP occurred and affected the emulsifying properties. There was, however, no evidence for these peptides interacting with each other in an aqueous environment (Fig. 2). Even if they interact with each other, the interaction could be restricted at an oil/water interface.

Studies on the effects of mixing the two different peptides on their emulsifying properties (Fig. 4) demonstrated that the mixing ratio seemed to be important for good emulsification. The fact that the adsorption ratio of the peptides at the oil globule surface changed depending on the mixing ratio suggests that the two peptides may be adsorbed at surfaces in a random mosaic, not in an ordered structure such as a bilayer where one peptide coats the other. Some interaction between $\beta$ $\mathrm{CN}(\mathrm{f} 193-209)$ and GMP may occur at the oil/water interface and stabilize the adsorbed layer.

It is generally recognized that a mixture of emulsifiers often gives better stabilization of the emulsion than a single emulsifier does at the same total concentration. The combination of an oil-soluble surfactant and a watersoluble surfactant is often successful. According to Elworthy et al. ${ }^{12)}$ the presence of the oil-soluble surfactant increases lateral interactions between adsorbed molecules in the film, thereby making it stronger and more condensed. Boyd et al. ${ }^{13,14)}$ suggested that the stronger affinity of the polyethylenenated derivatives of Span 80 for water induced the 
Tween hydrophobic chain to be extended slightly into the aqueous dispersion medium, thus allowing the adsorbed molecules to pack together more closely at the oil/water interface. Such a mechanism shown between the Span and Tween could be applied to peptides when used as emulsifiers. The intermolecular forces between the hydrophobic $\beta-\mathrm{CN}$ (f 193 209) and the hydrophilic GMP at the oil/water interface might strengthen the adsorbed peptide film and stabilize the emulsified oil droplets. The carbohydrate chain of the adsorbed GMP, which extends to the aqueous phase as observed in Table III and Fig. 5, also contributes to the better dispersion of the oil droplets.

It is considered that proteins are adsorbed to the oil globule surface and spread to form a thin film convering the oil droplets. ${ }^{15}$ ) Recently, Shimizu et al. ${ }^{16)}$ have suggested that $\alpha_{\mathrm{s} 1}$-casein is adsorbed onto the oil surface through multiple adsorption sites and thereby stabilizes the oil globules. Unlike proteins which could have multiple adsorption sites in the molecules, such peptides as $\beta$ - $\mathrm{CN}$ (f193209) might have only a few adsorption sites because of their short chain length. The lack of multiple adsorption sites might lead to prompt release of the peptides from the oil surface to the aqueous phase. This seems to cause the substantial coalescence of the globules. The presence of other peptides having different properties could give the peptides more adsorption sites by interacting with each other at the surface. In case of $\beta-\mathrm{CN}(\mathrm{f} 193-209)$ and GMP, interaction between these two peptides possibly produces an amphipathic complex which has both hydrophilic (GMP) and hydrophobic ( $\beta$-CN(f193-209)) moieties. Formation of such amphipathic complexes at the surface will be beneficial to reduce the surface tension and stabilize the surface film.
The mechanism of adsorption and emulsification by the caseins and the caseino peptides are thus considered to be different - caseins form an adsorbed layer by extending and spreading at the surface, while the peptides are likely to form a layer by packing together closely at the surface. The microscopic observation of the surface film of the emulsified oil globules prepared by $\beta$-casein (Fig. 6a) or $\beta$ $\mathrm{CN}(\mathrm{f} 193-209)+\mathrm{GMP}$ (Fig. 6b) might reflect such differences.

\section{REFERENCES}

1) J. Adler-Nissen and H. S. Olson, "Functionality and Protein Structure," ed. by A. Pour-El, American Chemical Society, Washington D. C., 1979, p. 125.

2) T. Horiuchi and D. Fukushima, Food Chem., 3, 35 (1978).

3) R. Jost, J. C. Monti, R. Baechler and D. Fumeaux, Lait, 62, 521 (1982).

4) C. A. Kuehler and C. M. Stine, J. Food Sci., 39, 379 (1974).

5) E. H. Rahma and M. S. N. Rao, J. Agric. Food Chem., 31, 356 (1983).

6) M. Shimizu, S. W. Lee, S. Kaminogawa and K. Yamauchi, J. Food Sci., 51, 1248 (1986).

7) S. W. Lee, M. Shimizu, S. Kaminogawa and K. Yamauchi, Agric. Biol. Chem., 51, 161 (1987).

8) P. F. Fox and J. Guiney, J. Dairy Res., 39, 49 (1972).

9) C. A. Zittle and J. H. Custer, J. Dairy Sci., 46, 1183 (1963).

10) K. N. Pearce and J. E. Kinsella, J. Agric. Food Chem., 26, 716 (1978).

11) H. Doi, F. Ibuki and K. Kanamori, J. Dairy Sci., 62, 195 (1979).

12) P. H. Elworthy, A. T. Florence and J. A. Rogers, $J$. Colloid Interface Sci., 35, 34 (1971).

13) J. Boyd, C. Parkinson and P. Sherman, J. Colloid Interface Sci., 41, 359 (1972).

14) J. Boyd, N. Krog and P. Sherman, "Theory and Practice of Emulsion Technology," ed. by A. L. Smith, Academic Press, Inc., London, 1976, p. 123.

15) E. Tornberg, J. Food Sci., 45, 1662 (1980).

16) M. Shimizu, A. Ametani, S. Kaminogawa and K. Yamauchi, Biochim. Biophys. Acta, 869, 259 (1986). 